\title{
Vaccination against hepatitis B with 4-double doses increases response rates and antibodies titers in HIV-infected adults
}

\author{
D.V. Potsch ${ }^{\mathrm{a}, *}$, L.A.B. Camacho ${ }^{\mathrm{c}}$, S. Tuboi ${ }^{\mathrm{d}}$, L.M. Villar ${ }^{\mathrm{b}}$, J.C. Miguel $^{\mathrm{b}}$, C. Ginuíno $^{\mathrm{b}}$, E.F. Silva $^{\mathrm{b}}$, \\ R.M.M. Mendonça ${ }^{a}$, R.B. Moreira ${ }^{a}$, P.F. Barroso ${ }^{a}$ \\ a HUCFF/FM - Universidade Federal do Rio de Janeiro, Brazil \\ b Laboratório de Referência Nacional Para Hepatites Virais, IOC/FIOCRUZ, Brazil \\ ${ }^{\mathrm{c}}$ ENSP/Fiocruz, Brazil \\ d Universidade Federal Fluminense, Brazil
}

\section{A R T I C L E I N F O}

\section{Article history:}

Received 17 May 2012

Received in revised form 5 July 2012

Accepted 12 July 2012

Available online 21 July 2012

\section{Keywords:}

Hepatitis B vaccination

HIV infection

Immune response

\begin{abstract}
A B S T R A C T
Background: Antibody responses to standard regimens of hepatitis B (HBV) vaccination are lower in HIVinfected subjects and the best hepatitis B vaccine schedule in this population is not known.

Objective: To assess the immunogenicity and to evaluate predictors of serologic response of a modified regimen of a HBV recombinant vaccine in a cohort of HIV-infected subjects.

Methods: HIV-infected subjects received 4 doses ( $40 \mu \mathrm{g}$ ) of a recombinant HBV vaccine at $0,1,2$ and 6 months. Demographic information as well as CD4 cell count and plasma viral load were assessed at baseline. Protective and strong responses were defined as an anti-HBs titer $\geq 10 \mathrm{mIU} / \mathrm{mL}$ and $\geq 100 \mathrm{mIU} / \mathrm{mL}$, respectively and were evaluated one month after the third and the fourth doses.

Results: 163 HIV-infected individuals were evaluated 67 (40\%) were male and median age was 37 years. Median CD4 cell count was 385 cells $/ \mathrm{mm}^{3}$ and 113 (70\%) had undetectable HIV-1 viral load. Protective antibody response was observed in 83 and $91 \%$ and a strong antibody response was observed in 62 and $80 \%$ of the subjects after 3 and 4 doses, respectively.

In a multivariate logistic model undetectable HIV-1 viral load and higher CD4 cell counts were independent predictors of a strong antibody response after 4 doses. Patients with undetectable HIV viral load were almost 3 times more likely to have anti-HBs titers above $100 \mathrm{mIU} / \mathrm{mL}$ than those with detectable viral load.

Conclusions: A 4-double-dose regimen of a recombinant HBV vaccine increased response rates and determined higher antibody titers which may translate in prolonged protection agains HBV. Inclusion of a fourth dose of HBV vaccine for HIV-infected subjects should be considered in the public health setting.
\end{abstract}

(C) 2012 Elsevier Ltd. All rights reserved.

\section{Introduction}

Hepatitis B virus (HBV) co-infection is responsible for high morbidity and mortality among Human Immunodeficiency Virus-1 (HIV)-infected subjects $[1,2]$. In recent years, deaths attributable to viral hepatitis complications are among the leading causes in this population [1]. Thus, improving HBV prevention by means of vaccination of people living with HIV/AIDS is of major importance. However, protective antibody responses to standard regimens of hepatitis B vaccination are lower among these subjects than in the general population, particularly in adulthood [3-8]. Moreover, these individuals experience more rapid decline of antibody titers and the clinical implications such as higher carriage rates.

\footnotetext{
* Corresponding author.

E-mail addresses: dvpotsch@openlink.com.br, dfvp@hucff.ufrj.br (D.V. Potsch).
}

Currently, there are no data to determine the best hepatitis B vaccine schedule for HIV-infected subjects. Several authors reported that a vaccination schedule consisting of 3-doses of $40 \mu \mathrm{g}$ of antigen (double the usual dose for adults) significantly improves the immune response, particularly in patients with higher CD4 cell count [9-12]. Similar approaches have proved effective in patients undergoing hemodyalisis and the other immunocompromised subjects [13].

The aim of this study was to assess the immunogenicity and safety of a 4-dose regimen with $40 \mu \mathrm{g}$ of recombinant vaccine and to evaluate predictors of serologic response and antibody titers in a cohort of HIV-infected subjects in Rio de Janeiro, Brazil.

\section{Patients and methods}

\subsection{Study design, setting and study population}

The study was conducted at the School of Medicine and the Hospital Universitário Clementino Fraga Filho (HUCFF-UFRJ) of the 
Universidade Federal do Rio de Janeiro from July 2005 to May 2009. A detailed description of study methods and preliminary data have been published [14] and are briefly presented in this section. An uncontrolled cohort of HIV-1-infected subjects was recruited at the outpatient unit of that hospital. HIV-infected adults subjects, 20-60 years of age, without serological evidence of previous HBV infection or immunization were invited to participate. Subjects were excluded if pregnant or if they had evidence of hepatitis $C$ infection, renal or hepatic chronic disease, malignancy or allergy to vaccine components.

A double dose $(40 \mu \mathrm{g})$ of a recombinant DNA HB vaccine (EUVAX B - LG Life Sciences, Korea) was given intramuscularly in the deltoid region at study entry and at 1,2 and 6 months thereafter. Blood samples for hepatitis B serology were collected prior to the first vaccination and 30-60 days after the third and fourth doses. Relevant clinical data were recorded in case report forms designed for the follow-up study. The study protocol was approved by the institutional review board of the School of Medicine and HUCFF-UFRJ and written consent forms were obtained from all participants.

\subsection{Study variables and outcome}

The following demographic and clinical information were assessed at baseline: age, gender, body mass index - BMI [15], smoking status, CDC Case Definition for HIV Infection Among Adults [16], HAART use, CD4 cell lymphocyte count and HIV-1 plasma viral load (PVL).

Serological assays of previous HBV infection (anti-HBc, anti-HBs and $\mathrm{HBsAg}$ ) were performed at baseline, according to manufacturers' recommendations. Anti-HBs titers (in $\mathrm{mIU} / \mathrm{mL}$ ) were measured in blood samples using commercial immunoassays (AxSYM ${ }^{\circledR}$ AUSAB $^{\circledR}$ - Abbott, USA) 30-60 days after the third and fourth doses. CD4 cell count, HIV-1 viral load and other laboratory tests for routine follow-up were performed at HUCFF-UFRJ. The detection limit for HIV-1 viral load was 80 copies $/ \mathrm{mL}$.

The main analysis assessed the rate and factors associated with seroprotection, defined by anti-HBs titers $\geq 10 \mathrm{mIU} / \mathrm{mL}$ [16] after the third and fourth doses. A secondary analysis assessed the rate and factors associated with strong antibody response, defined as anti-HBs $\geq 100 \mathrm{mIU} / \mathrm{mL}$ (Hadler, 1986; [17-19]) after the third and fourth doses.

Signs and symptoms, both systemic and on the injection site, were recorded following vaccination to monitor the reactogenicity.

\subsection{Statistical analysis}

Univariate analyses were performed using $x^{2}$ or Fisher exact test for categorical variables, and Student's $t$ test or Wilcoxon test for continuous variables. Reverse cumulative distribution of the logarithm (base 10) of antibody titers based on serological tests after the third and the fourth doses of the vaccine was plotted [20]. Seroconversion rates were estimated and the association with relevant covariates was measured by the odds ratio (OR) and 95\% CIs. Variables with a $p$ value $<0.10$ in the univariate analysis were included in the multivariate analyses. We used a stepwise approach to assess factors independently associated with outcome. All the $p$ values are 2-sided.

\section{Results}

\subsection{Study population}

One hundred and seventy four HIV-infected individuals (101 females and 73 males) were evaluated for participation in the study. One subject was excluded due to positive anti-HBc and anti-HBs
Table 1

Baseline characteristic of the 163 patients.

\begin{tabular}{ll}
\hline Variables & Median (IQR), $n / n(\%)$ \\
\hline Median age (years) & $37(30-43)$ \\
Gender (male) & $67 / 163(40 \%)$ \\
BMI $\left(\mathrm{kg} / \mathrm{m}^{2}\right)$ & $25(22-27)$ \\
BMI categories $\left(\mathbf{k g} / \mathbf{m}^{2}\right)(\%)$ & \\
$\geq 25 \mathrm{~kg} / \mathrm{m}^{2}$ & $81(49 \%)$ \\
$<25 \mathrm{~kg} / \mathrm{m}^{2}$ & $82(50 \%)$ \\
Smoke & $29(18 \%)$ \\
HAART use $(\%)$ & $131 / 163(80 \%)$ \\
Time on HAART (months) & $19(7-27)$ \\
Median CD4 (cells/mm $\left.{ }^{3}\right)($ range $)$ & $385(293-485)$ \\
CD4 categories $\left(\mathbf{c e l l s} / \mathbf{m m}^{3}\right)(\%)$ & \\
$<200$ & $5(3 \%)$ \\
$200-349$ & $63(39 \%)$ \\
$350-499$ & $58(35 \%)$ \\
$\geq 500$ & $37(23 \%)$ \\
HIV viral load below detection limit $(\leq 80$ copies $/ \mathrm{mL})$ & $113(70 \%)$ \\
\hline
\end{tabular}

BMI, body mass index; HAART, highly active antiretroviral therapy.

after re-screening. One woman was found to be pregnant. Nine subjects did not complete the vaccination schedule $(5,1$ and 3 subjects received only 3, 2 and 1 doses, respectively) and were excluded from this analysis. We present data on 163 patients who completed the study protocol requirements (Table 1 ). No withdrawals were attributed to adverse events, and those were mild or moderate pain at the injection site.

Study subjects were predominantly females, median age 37 years, non-smokers, with substantial proportion of overweight or obese individuals. The great majority were on HAART, had CD4 cell counts above 350 cells $/ \mathrm{mm}^{3}$ and HIV load bellow detection limit.

\subsection{Serologic response and determinants}

Protective antibody response (anti-HBs $\geq 10 \mathrm{mIU} / \mathrm{mL}$ ) was observed in $136(83 \%)$ and 148 (91\%) of the subjects after 3 and 4 doses, respectively. Fig. 1 shows a substantial increase in the proportion of strong immune responses after the fourth dose. Individuals with an adequate serologic response after 4 doses were comparable to non-responders in respect to gender, age, BMI, smoking status, use of HAART, CD4 cell count and PVL. $72 \%$ of responders showed HIV-1 viral load below detection limit, compared with $47 \%$ non-responders $(p=0.05$ ) (data not shown). After adjustment for confounding of relevant covariates in the multivariable model this variable was the only predictor of seroconversion with 4 doses of the vaccine. Patients with undetectable viral load

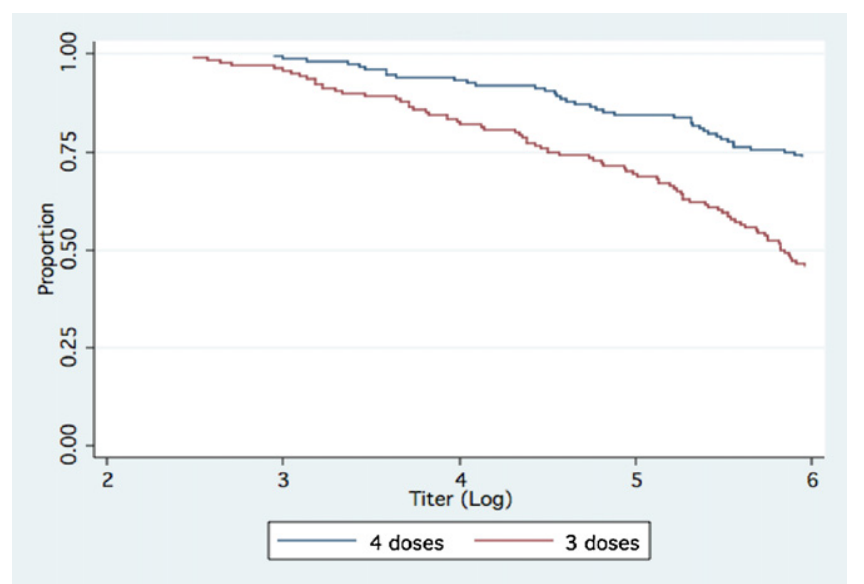

Fig. 1. Reverse cumulative distribution plot of proportion of subjects who showed seroprotection after 3 and 4 doses and antibody titers ( $\log$ ). 
Table 2

Predictors of serologic response (anti-HBs titer $\geq 10 \mathrm{mIU} / \mathrm{mL}$ ) among $163 \mathrm{HIV}$ infected subjects after four doses regimen of HBV vaccination-logistic model.

\begin{tabular}{lll}
\hline Variables & $\begin{array}{l}\text { Unadjusted } \\
\text { OR }(95 \% \mathrm{CI})\end{array}$ & $\begin{array}{l}\text { Adjusted } \\
\text { OR }(95 \% \mathrm{CI})\end{array}$ \\
\hline Sex (male) & $1.05(0.36-3.11)$ & \\
Age (years) & $0.96(0.90-1.02)$ & $0.95(0.89-1.01)$ \\
BMI $\left(\mathrm{kg} / \mathrm{m}^{2}\right)$ & $0.93(0.82-1.06)$ & \\
Smoke & $0.85(0.22-3.24)$ & \\
Baseline CD4 (cells $\left./ \mathrm{mm}^{3}\right)$ & $1.25(0.84-1.87)$ & \\
HIV viral load $\leq 80$ copies $/ \mathrm{mL}$ & $2.88(0.98-8.45)$ & $3.13(1.05-9.35)$ \\
\hline
\end{tabular}

BMI, body mass index.

at baseline were 3 times more likely to show a protective response than those with detectable viral load (Table 2).

\subsection{Strong antibody response and determinants}

Strong antibody response (anti-HBs $\geq 100 \mathrm{mIU} / \mathrm{mL}$ ) was observed in $101(62 \%)$ and 131 (80\%) of the subjects after 3 and 4 doses, respectively $(p<0.001)$.

Individuals with a strong antibody response after 4 doses were comparable to non-responders in respect to gender, age, BMI, smoking status, use of HAART, CD4 cell count and PVL. More strong responders showed HIV-1 viral load below detection limit and higher CD4 cell count, compared with non-responders. Study subjects with stronger immune responses to the third dose of the vaccine had on average slightly higher baseline CD4 cell counts (Fig. 2). After the fourth dose of the vaccine the distribuition of CD4 cell counts was very similar in responders and non-responders to the vaccine (Fig. 3).

Adjusting for the effects of relevant covariates in the multivariate model, HIV-1 viral load below detection limit and higher CD4 cell counts were the strongest predictors of strong antibody response (Table 3 ). Patients with undetectable viral load at baseline were almost 3 times more likely to show anti-HBs titers above $100 \mathrm{mIU} / \mathrm{mL}$ than those with detectable viral load. Analogously higher baseline CD4 cell counts were also associated with higher anti-HBs titers.

Among 95 subjects with CD4 $\geq 350$ cells $/ \mathrm{mm}^{3}, 85 \%$ and $93 \%$ showed protective response, after 3 and 4 doses, respectively. Seventy-three and $85 \%$ showed a strong antibody response, after 3 and 4 doses, respectively.

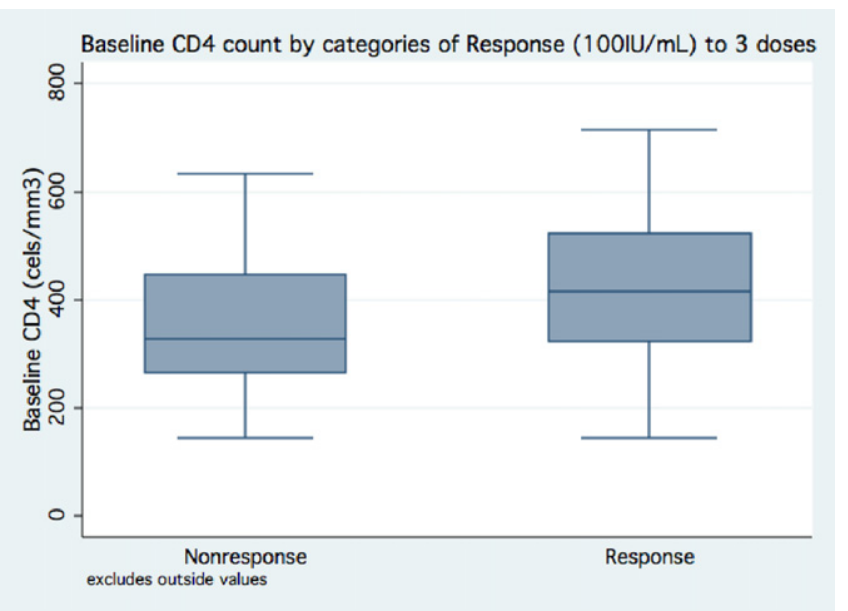

Fig. 2. Baseline CD4 cell count by categories of response (anti-HBs $\geq 100 \mathrm{mIU} / \mathrm{mL}$ and no response) to 3 doses.

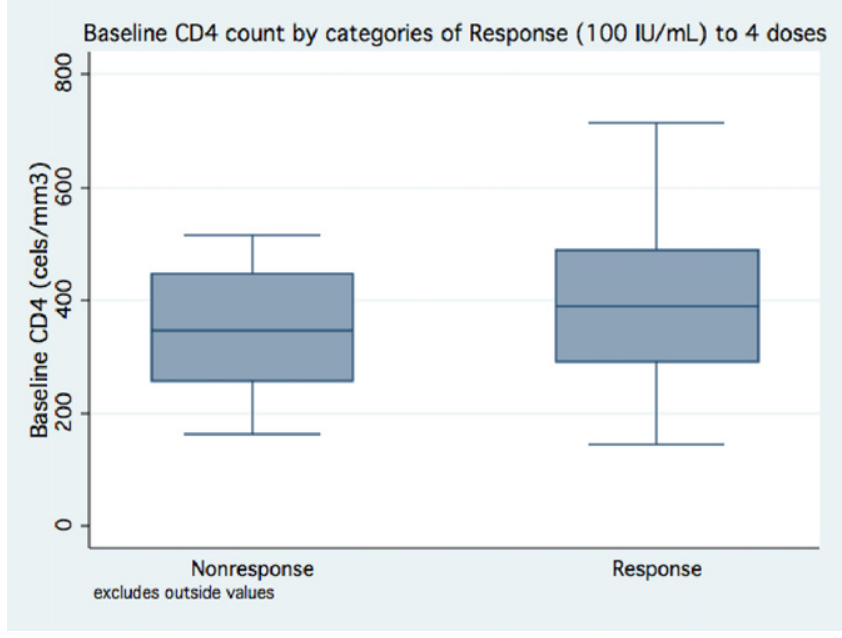

Fig. 3. Baseline CD4 cell count by categories of response (anti-HBs $\geq 100 \mathrm{mIU} / \mathrm{mL}$ and no response) to 4 doses.

\section{Discussion}

Our data showed that higher seroconversion rates were achieved in HIV-infected subjects with 4-double doses of a recombinant HBV vaccine on a 0-1-2-6-month schedule, compared to three-dose schedule. The 4-double-dose regimen also induced higher antibody titers which may result in prolonged protection agains HBV.

The proportion of subjects with evidence of seroprotection obtained in our study was similar to that reported by 2 others groups that also used 4 or more doses and higher antigen dose [21,22], and confirmed results obtained in our pilot study [14]. Moreover the seroprotection rates obtained with the regimen used in this study approached those seen with standard schedules in immunocompetent subjects $[18,23,24]$. This 4-double-doseschedule is already recommended for subjects in hemodialysis programmes, based on evidence of HBV seroprotection in high risk populations similar to that obtained in HBV vaccination in healthy adult [13].

Seroprotection rates observed in our study after 3 monthly double doses were effective in getting high rates of response and anti-HBs titers.

After the fourth dose we observed an improvement both in seroprotection and in strong antibody response when compared to what was observed after the third dose. That had also been observed in patients with renal diseases $[13,26]$ and support the recommendation of high anti-HBs titers in specific groups of immunocompromissed patients

As expected, subjects with HIV-1 viral load below detection limits had a higher probability of achieving protective titers $(\mathrm{OR}=3.13$; 95\% IC 1.05-9.35) when compared with those with detectable HIV viral load. The suppression of plasmatic HIV-1 viral load has been

Table 3

Predictors of strong antibody response (anti-HBs titer $\geq 100 \mathrm{mIU} / \mathrm{mL}$ ) among 163 HIV infected subjects after four doses regimen of HBV vaccination-logistic model.

\begin{tabular}{lll}
\hline Variables & $\begin{array}{l}\text { Unadjusted } \\
\text { OR }(95 \% \mathrm{CI})\end{array}$ & $\begin{array}{l}\text { Adjusted } \\
\text { OR }(95 \% \mathrm{CI})\end{array}$ \\
\hline Age (years) & $0.96(0.92-1.01)$ & $0.96(0.92-1.00)$ \\
Sex (male) & $0.87(0.40-1.90)$ & $0.72(0.30-1.69)$ \\
Baseline CD4 (cells $\left./ \mathrm{mm}^{3}\right)$ & $1.43(1.05-1.96)$ & $1.44(1.04-1.99)$ \\
HIV viral load $\leq 80$ copies $/ \mathrm{mL}$ & $2.85(1.29-6.32)$ & $2.87(1.26-6.56)$ \\
BMI & $0.93(0.84-1.02)$ & $0.94(0.84-1.04)$ \\
\hline
\end{tabular}

BMI, body mass index. 
reported as one of the variables associated with improved vaccination responses $[5,6,8,9,12,21,25,27]$. Improved immune responses to neoantigens have been observed in HIV individuals after HAART induced viral suppression $[6,28]$. In addition, restoration of number and function of the T lymphocytes and improved T-cell-mediated response to specific antigens has been reported $[27,29]$. When we examined seroprotection levels (anti-HBs titer $\geq 10 \mathrm{mIU} / \mathrm{mL}$ ) our results did not show association of CD4 cell count levels with vaccination responses reported by the others authors [3,5,8-12].

Interestingly, both HIV-1 viral load suppression ( $\mathrm{OR}=2.87$; 95\% CI: 1.26-6.56) and higher CD4 cell count (OR=1.44; 95\% CI: 1.04-1.99) were independent predictors of a strong antibody response (anti-HBs titer $\geq 100 \mathrm{mIU} / \mathrm{mL}$ ) after 4 double doses. Among patients with CD4 cell counts greater than 350 cells $/ \mathrm{mm}^{3}$, a strong antibody response was higher after 4 doses than after 3 doses. This is in line with previous reports of higher anti-HBs titers associated with higher CD4 levels [11,12]. Altogether, there is evidence to support the recommendation to delay HBV vaccination until HIV-1 viral load suppression and CD4 cells count greater than 350 cells $/ \mathrm{mm}^{3}$ are obtained after HAART introduction.

Antibody persistence is correlated with highest anti-HBs levels after vaccination [17,21,23,30,31]. Among immunocompetent subjects the protection against HBV is preserved by means of the subject's immune memory - in whom ever after decrease of antibody detection, or even after antibody loss [32]. Conversely, in immunodeficient subjects such decline may correspond to a loss of protection $[17,26,33,34]$. Therefore, to assess immunization outcome anti-HBs $\geq 100 \mathrm{mIU} / \mathrm{mL}$ titer is often prefered as a correlate of larger and longer protection against infection, specially in high risk subjects $[17,19]$.

The length of follow-up in our study was not long enough to confirm those assumptions. In addition, we did not have a external three-dose HIV-infected group to confirm the differences observed between the 3 and 4 dosis group. Despite those limitations, the high frequency of antibody responses with the proposed regimen in our study suggested that there was in fact an improved response.

In immunocompetent subjects, the third dose of the standard anti-HBV vaccination is necessary to increase response rate and offer long-term protection [35]. For HIV-infected subjects, the US Advisory Committee on Immunization Practices (ACIP) recommends vaccination against $\mathrm{HBV}$ with standard schedule (3 doses of $20 \mathrm{mg}$ of hepatitis B virus recombinant vaccine), followed by two or three additional doses for those subjects that do not achieve adequate serologic response [7]. This strategy includes multiple patient visits and laboratory work that may compromise adherence, especially in resource poor settings. In contrast, others guidelines recommend that HIV-positive adults receive a larger dose of HBV recombinant vaccine $[35,36]$.

In summary, our data confirm that a fourth dose, in a 0-1-2-6month regimen of $40 \mu \mathrm{g}$ per dose significantly improves both response rates and magnitude of immune response to recombinant hepatitis B vaccine in HIV-infected patients, without increasing reactogenicity. This strategy should be considered in the public health setting in order to reduce the burden of hepatitis B virus related disease among people living with HIV.

\section{References}

[1] Thio CL, Seaberg EC, Skolasky Jr R, Phair J, Visscher B, Munoz A, et al. HIV-1, hepatitis B virus, and risk of liver-related mortality in the Multicenter Cohort Study (MACS). Lancet 2002;360(December (9349)):1921-6.

[2] Konopnicki D, Mocroft A, de Wit S, Antunes F, Ledergerber B, Katlama C, et al. Hepatitis B and HIV: prevalence, AIDS progression, response to highly active antiretroviral therapy and increased mortality in the EuroSIDA cohort. AIDS 2005;19(24 (6)):593-601.

[3] Bruguera M, Cremades M, Salinas R, Costa J, Grau M, Sans J. Impaired response to recombinant hepatitis B vaccine in HIV-infected persons. J Clin Gastroenterol 1992;14(January (1)):27-30.
[4] Keet IP, van Doornum G, Safary A, Coutinho RA. Insufficient response to hepatitis B vaccination in HIV-positive homosexual men. AIDS 1992;6(May (5)):509-10.

[5] Tedaldi EM, Baker RK, Moorman AC, Wood KC, Fuhrer J, McCabe RE, et al. Hepatitis $A$ and $B$ vaccination practices for ambulatory patients infected with HIV. Clin Infect Dis 2004;38(May (10)):1478-84.

[6] Overton ET, Sungkanuparph S, Powderly WG, Seyfried W, Groger RK, Aberg JA. Undetectable plasma HIV RNA load predicts success after hepatitis B vaccination in HIV-infected persons. Clin Infect Dis 2005;41(October (7)):1045-8.

[7] Mast EE, Weinbaum CM, Fiore AE, Alter MJ, Bell BP, Finelli L, et al. A comprehensive immunization strategy to eliminate transmission of hepatitis $B$ virus infection in the United States: recommendations of the Advisory Committee on Immunization Practices (ACIP) Part II: immunization of adults. MMWR Recomm Rep 2006;55(December (RR-16)):1-33.

[8] Kim HN, Harrington RD, Van Rompaey SE, Kitahata MM. Independent clinical predictors of impaired response to hepatitis B vaccination in HIV-infected persons. Int J STD AIDS 2008;19(September (9)):600-4.

[9] Fonseca MO, Pang LW, de Paula Cavalheiro N, Barone AA, Heloisa Lopes M. Randomized trial of recombinant hepatitis B vaccine in HIV-infected adult patients comparing a standard dose to a double dose. Vaccine 2005;23(April (22)):2902-8.

[10] Cornejo-Juarez P, Volkow-Fernandez P, Escobedo-Lopez K, Vilar-Compte D, Ruiz-Palacios G, Soto-Ramirez LE. Randomized controlled trial of Hepatitis B virus vaccine in HIV-1-infected patients comparing two different doses. AIDS Res Ther 2006;3:9.

[11] Pasricha N, Datta U, Chawla Y, Singh S, Arora SK, Sud A, et al. Immune responses in patients with HIV infection after vaccination with recombinant Hepatitis B virus vaccine. BMC Infect Dis 2006;6:65.

[12] Veiga AP, Casseb J, Duarte AJ. Humoral response to hepatitis B vaccination and its relationship with T CD45 RA+ (naive) and CD45 RO+ (memory) subsets in HIV-1-infected subjects. Vaccine 2006;24(November (49-50)):7124-8.

[13] Recommendations for preventing transmission of infections among chronic hemodialysis patients. MMWR Recomm Rep 2001;50(April (RR-5)):1-43.

[14] Potsch DV, Oliveira ML, Ginuino C, Miguel JC, Oliveira SA, Silva EF, et al. High rates of serological response to a modified hepatitis $B$ vaccination schedule in HIV-infected adults subjects. Vaccine 2010;28(February (6)):1447-50.

[15] Physical status: the use and interpretation of anthropometry. Report of a WHO Expert Committee. World Health Organ Tech Rep Ser 1995;854:1-452.

[16] Revised surveillance case definitions for HIV infection among adults, adolescents, and children aged $<18$ months and for HIV infection and AIDS among children aged 18 months to $<13$ years - United States. MMWR Recomm Rep 2008;57(December (RR-10)):1-8.

[17] Hadler SC, Francis DP, Maynard JE, Thompson SE, Judson FN, Echenberg DF, et al Long-term immunogenicity and efficacy of hepatitis $B$ vaccine in homosexual men. N Engl J Med 1986;315(July (4)):209-14.

[18] Bock HL, Kruppenbacher J, Sanger R, Hobel W, Clemens R, Jilg W. Immunogenicity of a recombinant hepatitis $B$ vaccine in adults. Arch Intern Med 1996;156(October (19)):2226-31.

[19] Hofmann F, Kralj N. Criteria for successful hepatitis B vaccination in adults: results of a case study. Infection 2009;37(June (3)):266-9.

[20] Reed GF, Meade BD, Steinhoff MC. The reverse cumulative distribution plot: a graphic method for exploratory analysis of antibody data. Pediatrics 1995;96(September (3 Pt 2)):600-3.

[21] Cruciani M, Mengoli C, Serpelloni G, Lanza A, Gomma M, Nardi S, et al. Serologic response to hepatitis B vaccine with high dose and increasing number of injections in HIV infected adult patients. Vaccine 2009;27(January (1)):17-22.

[22] Launay O, van der Vliet D, Rosenberg AR, Michel ML, Piroth L, Rey D, et al. Safety and immunogenicity of 4 intramuscular double doses and 4 intradermal low doses vs standard hepatitis B vaccine regimen in adults with HIV-1: a randomized controlled trial. JAMA 2011;305(April (14)):1432-40.

[23] Jilg W, Schmidt M, Deinhardt F. Vaccination against hepatitis B: comparison of three different vaccination schedules. J Infect Dis 1989;160(November (5)):766-9.

[24] Hepatitis B virus: a comprehensive strategy for eliminating transmission in the United States through universal childhood vaccination. Recommendations of the Immunization Practices Advisory Committee (ACIP). MMWR Recomm Rep 1991;40(November (RR-13)):1-25.

[25] de Vries-Sluijs TE, Hansen BE, van Doornum GJ, Springeling T, Evertsz NM, de Man RA, et al. A prospective open study of the efficacy of high-dose recombinant hepatitis B rechallenge vaccination in HIV-infected patients. J Infect Dis 2008;197(January (2)):292-4.

[26] Stevens CE, Alter HJ, Taylor PE, Zang EA, Harley EJ, Szmuness W. Hepatitis B vaccine in patients receiving hemodialysis. Immunogenicity and efficacy. N Engl J Med 1984;311(August (8)):496-501.

[27] Lao-araya M, Puthanakit T, Aurpibul L, Sirisanthana T, Sirisanthana V. Antibody response to hepatitis $B$ re-vaccination in HIV-infected children with immune recovery on highly active antiretroviral therapy. Vaccine 2007;25(July (29)):5324-9.

[28] Valdez H, Smith KY, Landay A, Connick E, Kuritzkes DR, Kessler H, et al. Response to immunization with recall and neoantigens after prolonged administration of an HIV-1 protease inhibitor-containing regimen. ACTG 375 Team. AIDS Clinical Trials Group. AIDS 2000;14(January (1)):11-21.

[29] Pontesilli O, Kerkhof-Garde S, Notermans DW, Foudraine NA, Roos MT, Klein MR, et al. Functional T cell reconstitution and human immunodeficiency virus1-specific cell-mediated immunity during highly active antiretroviral therapy. J Infect Dis 1999;180(July (1)):76-86. 
[30] Gesemann M, Scheiermann N. Quantification of hepatitis B vaccine-induced antibodies as a predictor of anti-HBs persistence. Vaccine 1995;13(April (5)):443-7.

[31] Floreani A, Baldo V, Cristofoletti M, Renzulli G, Valeri A, Zanetti C, et al. Long-term persistence of anti-HBs after vaccination against HBV: an 18 year experience in health care workers. Vaccine 2004;22(January (5-6)): 607-10.

[32] McMahon BJ, Bruden DL, Petersen KM, Bulkow LR, Parkinson AJ, Nainan $O$, et al. Antibody levels and protection after hepatitis B vaccination: results of a 15-year follow-up. Ann Intern Med 2005;142(March (5)): 333-41.
[33] Biggar RJ, Goedert JJ, Hoofnagle J. Accelerated loss of antibody to hepatitis B surface antigen among immunodeficient homosexual men infected with HIV. N Engl J Med 1987;316(March (10)):630-1.

[34] Hadler SC. Hepatitis B prevention and human immunodeficiency virus (HIV) infection. Ann Intern Med 1988;109(July (2)):92-4.

[35] Australian Technical Advisory Group on Immunization (ATAGI). The Australian immunization handbook. 9th ed Canberra: Australian Government, Department of Health and Ageing; 2008.

[36] Ministerio da Saude do Brasil, Fundação Nacional de Saúde. Recomendações para vacinação em pessoas infectadas pelo HIV. Brasília, DF: Ministério da Saúde; 2002. 